\title{
Efeito da sacarose e da forma de arraçoamento sobre alguns parâmetros reprodutivos da leitoa*
}

\author{
BEATRIZ DE FELIPPE PERUZZO \\ Ivo Wentz (Orientador - UFRGS) \\ Fernando Pandolfo Bortolozzo (Co-orientador - UFRGS)
}

Banca: Antônio Mário Penz Jr. (UFRGS), Guilherme Borchadt Neto (UNICRUZ), Mari Lourdes Bernardi (UFRGS)

\begin{abstract}
O trabalho foi realizado, no período de outubro a dezembro de 1996. Foram utilizadas 80 fêmeas híbridas F1, oriundas de cruzamentos de Landrace e Large White distribuídas aleatoriamente em quatro tratamentos: T1 - fornecimento de ração sem glicose e de forma restrita, $2 \mathrm{~kg}$ ao dia (duas vezes ao dia); T2 - fornecimento de ração sem glicose e à vontade; T3 fornecimento de ração com $20 \%$ de glicose e de forma restrita, $2 \mathrm{~kg}$ ao dia (duas vezes ao dia), e, T4 - fornecimento de ração com $20 \%$ de sacarose, à vontade. Como fonte de glicose foi utilizado o açúcar cristal. A ração continha $3.150 \mathrm{kcal} / \mathrm{Kg}$ de E.D., $14 \%$, de proteína bruta, 0,65 de lisina, $0,9 \%$ de cálcio e $0,45 \%$ de fósforo disponível. Todas as fêmeas foram pesadas individualmente ao alojamento e na apresentação do $1^{\circ} \mathrm{e}$ do $2^{\circ}$ estro. Os tratamentos foram aplicados no momento em que as fêmeas manifestaram o $1^{\circ}$ estro e terminaram quando estas apresentaram o $2^{\circ}$ estro. As fêmeas foram inseminadas artificialmente (IA) no $2^{\circ}$ estro e abatidas 28-34 dias após para a contagem do número de ovulações e número de embriões viáveis. Foram analisados, os dados referentes à taxa de prenhez, a taxa de sobrevivência embrionária e a taxa de retorno ao estro. A taxa de ovulação das fêmeas do T4 foi superior aquelas das fêmeas dos T1 e T3 (respectivamente 17,80; 15,26; 15,60) (p $\leq 0,01)$. T4 foram diferentes quanto ao número de embriões viáveis daquelas do T1 (1,94 a mais; $\mathrm{p} \leq 0,03)$, do $\mathrm{T} 2(1,27$ a mais; $\mathrm{p} \leq 0,05)$ e do T3 (3,6 a mais; $\mathrm{p} \leq 0,01)$. Na análise do contraste ração restrita (T1 e T3) vs. ração à vontade (T2 e T4), foi observada um aumento do número de ovulações $(15,38$ vs 17, 34, respectivamente; $\mathrm{p}<0,01)$ e também no número de embriões viáveis (11,52 vs 13,64, respectivamente; $\mathrm{p}<0,04)$. As fêmeas que receberam ração com açúcar ( $\mathrm{T} 3$ e T4) não diferiram $(\mathrm{p}>0,05)$ dos que receberam ração sem açúcar (T1 e T2), nas variáveis estudadas. $\mathrm{O}$ arraçoamento à vontade, independente da adição de sacarose, foi efetivo no aumento do número médio de ovulações e número médio de embriões viáveis. Apesar do maior número de ovulações, a taxa de sobrevivência embrionária não foi diferente entre os tratamentos. As taxas de prenhez e retorno ao estro também não apresentaram diferenças as fêmeas dos diferentes tratamentos.
\end{abstract}

Descritores: leitoa, flushing, glicose, sobrevivência embrionária.

Apresentada: 3 janeiro 2000

"Dissertação de Mestrado n.262 (Especialidade: Sanidade Suína). 77f. Programa de Pós-graduação em Ciências Veterinárias [www.ufrgs.br/ ppgcv], Faculdade de Veterinária, Universidade Federal do Rio Grande do Sul(UFRGS), Porto Alegre/RS. CORRESPONDÊNCIA: B.F. Peruzzo [beatrizperuzzo@superip.com.br]. 


\title{
Effect of sacarose and feeding regime on some reproductive parameters of gilts ${ }^{* *}$
}

\author{
BEATRIZ DE FELIPPE PERUZZO
}

Ivo Wentz (Adviser - UFRGS)

Fernando Pandolfo Bortolozzo (Co-Adviser - UFRGS)

Commitee: Antônio Mário Penz Jr. (UFRGS), Guilherme Borchadt Neto (UNICRUZ), Mari Lourdes Bernardi (UFRGS)

This study was carried out in the western region of the state of Santa Catarina, Brazil, from October to December of 1996. Eighty hybrid (Landrace x Large White) females were distributed at random into four treatments: T1 - restricted feeding, ( $2 \mathrm{~kg}$ daily, twice a day) feed with no glucose; T2 - ad libitum feeding, feed with no glucose; T3 - restricted feeding ( $2 \mathrm{~kg}$ daily, twice a day), feed with $20 \%$ glucose,; T4 - ad libitum feeding, feed with $20 \%$ sacarose. Granulated sugar was the source of glucose. The feed contained 3,150 kcal $/ \mathrm{kg}$ DE, $14 \%$ crude protein, 0.65 lysine, $0.9 \%$ calcium and $0.45 \%$ available phosphorus. All gilts were individually weighed at housing and at $1^{\text {st }}$ and $2^{\text {nd }}$ oestrus manifestations. Treatments started to be submitted when the females manifested the $1^{\text {st }}$ oestrus and ended at the manifestation of the $2^{\text {nd }}$ oestrus. Gilts were artificially inseminated (AI) at the $2^{\text {nd }}$ oestrus and slaughtered 28-34 days later in order to count number of ovulations and number of viable embryos. Pregnancy rate, embryo survival rate and return to oestrus rate data were analyzed. Pregnancy rate of T4 females was higher ( $\mathrm{p} \leq 0,01$ ) than T1 and T3 females $(17.80 ; 15.26 ; 15.60$, respectively).T4 produced higher number of viable embryos as compared to T1 (1.94 more embryos, $\mathrm{p} \leq 0,03$ ); T2 (1.27 more embryos, $\mathrm{p} \leq 0,05)$; and T3 (1.94 more embryos, $\mathrm{p} \leq 0,01)$. The analysis of the contrast restricted feeding (T1 and T3) vs. ad libitum feeding (T2 and T4) showed an increase in the number of ovulations (15,38 vs. 17, 34 , respectively; $\mathrm{p}<0,01)$ and in the number of viable embryos (11.52 vs. 13.64 , respectively; $\mathrm{p}<0,04)$. There was no difference ( $p>0.05$ ) in these parameters in gilts offered feed with sugar (T3 and T4) as compared with those which received feed with no sugar (T1 and T2). Ad libitum feeding, independent from the addition of glucose, was an effective means to increase the mean number of ovulations and the mean number of viable embryos. Despite the higher number of ovulations, embryo survival rates were not different among treatments, as well as pregnancy and return to oestrus rates.

Keywords: gilt, flushing, glucose, embryo survival. 